\title{
Gerçekliğin Toplumsal İnşasında Bilgi ve Bilgi Merkezi*
}

\section{Knowledge and Information Centre in the Social Construction of Reality}

Bülent YILMAZ*

\begin{abstract}
Öz
Gerçeklik, insandan bağımsız olarak varolan, toplumsal olarak yapılandırılan kendinde nesneler dünyasıdır ve insanların onun hakkındaki bilgileri kadar değişkendir. Söz konusu gerçeklik hakkında bize açıklama getirecek bilgimiz yoksa gerçeklik de yoktur. "Bilgi süreçlerinin başarısı" biçiminde tanımlanabilecek toplumsal gerçeklik bize gösterildiği ölçüde vardır. Gerçeklik, bilgi ile yapılandırılan, anlamlandırılan ve iletilen bir olgudur.

Bu çalışmada, toplumsal gerçekliğin oluşturulmasında bilgi ve bilgi taşıyıcısı olarak bilgi merkezinin (kütüphane, arşiv dokümantasyon merkezi vb.) işlevleri irdelenmektedir. Gerçekliğin oluşturulmasında bilgi merkezinin toplumsal işlevi, "bildiğimden ötede gerçeklik yoktur; benim bilmediğim gerçeklik, gerçeklik değildir" varsayımı üzerine temellendirilmektedir. Çalışmada, bilginin ve onun aracısı olarak bilgi merkezinin "gerçekliğe varlık kazandıran ve onu anlamlandıran" rolü bilgi yönetimi alanının kuramsal yapısı açısından değerlendirilmiştir. Yapılan değerlendirmede "Bilgi merkezi önemlidir!" önermesi konu bağlamında temellendirilmeye çalışılmıştır.
\end{abstract}

Anahtar sözcükler: Bilgi, Bilgi sosyolojisi, Bilgi merkezleri, Toplumsal inşacılık

\begin{abstract}
Reality, that exists independently from human beings and can be constituted socially, contains a world of objects in itself and is changeable according to the changes in the acquired knowledge. In that sense, if our knowledge providing us with an explanation about the reality does not exist, nor does the reality itself. Social reality being defined as "the achievement of knowledge process" exists to the extent as much as we are aware of it. Therefore, reality is a phenomenon, which can be constructed, interpreted and conveyed through the existence of knowledge about it.
\end{abstract}

\footnotetext{
ÜNAK'08. Bilgi: Farklılık ve Farkındalık, 9-11 Ekim 2008 Yaşar Üniversitesi, İzmir konferansında sunulan bildirinin gözden geçirilmiş metnidir.

"Prof. Dr.; Hacettepe Üniversitesi Edebiyat Fakültesi Bilgi ve Belge Yönetimi Bölümü Beytepe Ankara (byilmaz@hacettepe.edu.tr)
} 


\begin{abstract}
In the present study, the functions of information centres (ie. eg. libraries, archives, documentation centres etc.) as the reality itself, and also as the conveyor of reality in developing the social reality has been investigated. The social function of the information centre in developing the reality depends upon the assumption that, "the reality cannot be beyond my knowledge; the reality I am not aware of is not a reality". In this study, the role of knowledge and the information centre as a means of knowledge in 'causing the existence of knowledge and explaining it' is to evaluate in terms of the structure underlying information management domain. Thereby, the hypothesis "information centre is important for that very reason" has also been assessed.
\end{abstract}

Keywords: Knowledge, Sociology of knowledge, Information centres, Social constructivism

\title{
Giriş
}

İki ayağının üzerine kalkarak ilk aleti yapan ve böylece toplumsal yaşamı başlatan insan için evrende, doğada ve toplumda varolan/gerçekleşen her şey "gerçeklik" anlamına gelmektedir. İnsan, kendisinin de parçası olduğu bu gerçekliği bilmek ve anlamak zorundadır. Bu zorunluluk, içinde yaşadığı gerçekliği çeşitli nedenlerle değiştirme çabasında oluşundan kaynaklanmaktadır. Kültür adını verdiğimiz bu değiştirme çabası insana varlık/kimlik kazandıran ve geliştiren etkinlikler toplamıdır. Yaşadığı gerçekliği bilmeyen ya da kavramayan insan yaşamı geliştiremez ve dolayısıyla uygarlık yaratamaz. Bilim, sanat, edebiyat, teknoloji, felsefe vb. uygarlık alanlarında yeni şeyler üretebilmek en başta varolan "gerçekliğin" bilinmesine, algılanmasına bağlıdır. Bir aradaki yaşamını "toplum" adı verilen ileri örgütlenme içinde sürdürme aşamasına ulaşması, insan için işlevi yukarıda vurgulanan "bilmek" eylemini de diğer bütün etkinlikleri gibi bu mekanizma (toplum) içinde gerçekleştirmeye başlamasına yol açmıştır. Böylece, bilmek, gerçekliği kavrama yoluyla o gerçekliğe, bir anlamda varlık kazandırmak anlamına gelmiştir. Bir başka deyişle, insan, artık toplum dediğimiz yapı aracılığıyla gerçekliği bilmeye, kendisi için "var kılmaya" ve onu geliştirmeye/ değiştirmeye başlamıştır. Örneğin, bilim bu çabanın en sağlam ve somut alanlarından birisidir.

Gerçekliği "bilme" aracılığıyla var kılma çabasının görüngüleri arasında sayabileceğimiz ve "kayıtlı bilginin elde edilmesi, düzenlenmesi, korunması ve kullanıma sunulması ile ilgili ilke, teknik ve yöntemleri geliştirmeye ilişkin bilgi alanı" olarak tanımlanabilecek Bilgi ve Belge Yönetimi'nin (Kütüphanecilik-Arşivcilik-Dokümantasyon ve Enformasyon) birisi "bilimsel" diğeri "mesleki" olmak üzere başlıca iki boyutunun olduğu söylenebilir. Sözü edilen alanın bilimsel yanı, "bilginin toplumsallaşma sürecine ilişkin genel ilkeleri belirleme/geliştirme", mesleki yanı ise "ilgili bilim dalının belirlediği/geliştirdiği bu ilkeleri uygulamaya aktarma süreci” olarak özetlenebilir. Gerek bilimsel gerekse mesleki boyutun üzerinde temellendiği ana olgu ise "bilgi"dir. İlki bilginin toplumsallaşma ilkelerini, diğeri bilginin toplumsallaşma uygulamasını ifade eder. Sözünü ettiğimiz alanın bilimsel yanının güçlenmesi mesleki boyutun yani uygulamanın derinleşmesi ve genişlemesine neden olurken, uygulamada elde edilen 
gelişmeler bilimsel içeriğin zenginleşmesine katkı sağlamaktadır. Dolayısıyla, Bilgi ve Belge Yönetimi alanı bilgi üzerine temellenmiş, varlığını ve kimliğini bilgi nesnesinin belirlediği/biçimlendirdiği bir toplumsal etkinlik alanıdır. Bu çerçevede, "bilgi merkezi" (kütüphane, arşiv vb.) adı verilen kuruluşu da "uygulamaya geçirilmiş bilgi yönetimi"nin bir aracı ya da ürünü olarak tanımlamak yanlış olmayacaktır.

Çeşitli açılardan bilgi olgusu bağlamında sözü edilen alana yönelik olarak yapılacak kuramsal çalışmaların sağlayacağı katkı hem bilim hem de uygulama boyutuna yansıyacaktır. Özellikle, Türkçe literatürde alanın kuramsal yapısını diğer bilgi alanlarının kuramsal olanaklarından yararlanarak güçlendirmeye yönelik yeterince çalışma olduğunu söylemek güçtür.

Ayrıca, Bilgi Yönetimi alanının kuramsal yapısının sorunlu olduğu da açıktır. * Daha önce yaptığımız bir çalışma (Yılmaz, 2007) burada ele alınan "toplumsal gerçekliğin inşası" kavramına bir alt konu olarak ve genel çizgileri ile değinen içerikte idi. Sözü edilen kavramın geliştirilmesi çabasının yansıması sayılacak bu çalışma, gerçekliği toplumsal olarak oluşturmada ya da var kılmada bilgi ve bilgi merkezinin işlevini kuramsal düzeyde irdelemeyi amaçlamaktadır.

\section{Temel Kavramlar}

Ele alınan konuda temel kavramların gerçek, gerçeklik, inşa, toplum, toplumsal, bilgi ve bilgi merkezi olduğu söylenebilir. Sıralanan kavramların tanımlanması konunun kuramsal olarak yapılandırılmasında zorunlu görünmektedir.

Çeşitli anlam boyutlarına sahip olmasına karşın konumuz bağlamındaki terim anlamıla, gerçek; "bir durum, bir nesne ya da bir nitelik olarak var olan, varlığı yadsınmayan, olgu durumunda olan" (TDK, 1983, s. 439) biçiminde tanımlanmaktadır. Gerçek, elle tutulur, gözle görülür diğer bir deyişle duyularımız ile algılayabildiğimiz şeydir. Ay, elma, kedi, deprem, Ali, düğün vb. gerçek'e örnek olarak düşünebileceğimiz nesne, durum ve olgulardır. Gerçeklik ise, kısaca, "gerçek ile ilgi olan" biçiminde tanımlanabilir. Denkel (1998, s.135) gerçeklik kavramını felsefik anlamıyla, "Kendinde olduğu gibi evren. Kendinde nesnelerin dünyası. Dış dünya" olarak tanımlamaktadır. "Gerçek'in sıfat durumu diyebileceğimiz gerçeklik çoğu zaman gerçek kavramı ile aynı anlamda ve onun yerine kullanılabilmektedir.

Inşa; "yapı kurma, yapı yapma, kurma" anlamına gelirken, inşa etmek; "kurmak, yapmak" anlamı taşır. Oluşturmak anlamıyla da düşünülebilecek inşa etmek, genelde "yapı", ya da "yapılandırma" kavramını içeren bir görünüm sergiler. "Tezinizi bu veriler üzerine inşa edemezsiniz!” önermesi bu anlamları yansıtan bir örnek olarak düşünülebilir.

"Bu konuda kapsayıcı bir çalışma için bkz. Yontar, 2004. 
"Tarihsel gelişim içinde, belirli bir üretim ilişkisinin belirli bir aşamasında bir arada yaşayan insanların tümü” (TDK, 1983, s. 440) biçiminde tanımlanan toplum kavramını, Kongar (2002, ss. 41-45) "sosyo-kültürel bir olay, bir sistem, kendi kendini sürdüren bir varlık, kendi kendine yeterli bir varlık ve sınıflar arası bir etkileşim süreci" olarak görmektedir. Aynı yazarın bir başka tanımında toplum; insan ömründen uzun yaşayan, göreli bir kararlılık ile ortak değer ve davranışlara sahip olan ve kendi kendini devam ettiren bir insan topluluğu olarak tanımlanmaktadır. Türkçede "-sal" ekinin isme kattığı “... ile ilgili”, “...na ilişkin” anlamları bağlamında düşünüldüğünde, toplumsal terimi "toplumla ilgili, topluma ilişkin" biçiminde içeriklendirilebilir.

İrdelenen konuya bağlı olarak çeşitli biçimlerde tanımlanabilecek ${ }^{* *}$ bilgi kavramını biz burada "gerçeğin/gerçekliğin kayıt altına alınmış ifadeleri" ya da "gerçeğe/gerçekliğe ilişskin kayıtlı açıklamalar" olarak ele alacağız. Bilgi merkezi de "bilgiyi toplumsallaştıran, yani bilgiyle toplumu buluşturan, bilgi taşıyıcısı kurumlar" biçiminde düşünülmüştür. Kuşkusuz, toplumsal yapıda kütüphane, arşiv, dokümantasyon merkezinin dışında da bilgi merkezlerinin bulunduğu açıktır. Üniversite, enstitü, lise vb. gibi kuruluşlar da bilgi merkezi niteliğine sahiptir. Ancak, kütüphane, arşiv, dokümantasyon merkezini sözü edilen türde diğer bilgi merkezlerinden farklılaştıran işlev, "kayıtı bilginin yeni bilgi üretimi için kullanılmasına olanak sağlamak" biçiminde tanımlanabilir. Bu çalışmada, bilgi merkezi kavramı kütüphane, arşiv, dokümantasyon-enformasyon merkezi içeriğinde kullanılmaktadır.

\section{Gerçekliğin Toplumsal İnşası}

Yukarıda tanımlanmaya çalışılan kavramlar ışığında bilgi ve bilgi merkezinin işlevlerini ele alınan konu açısından irdeleyebilmek için öncelikle "gerçekliğin toplumsal inşası" olgusunu tartışmakta yarar bulunmaktadır. "Gerçekliğin toplumsal inşası” kavramı, kısaca, gerçekliğin toplumsal yapı ve mekanizmalar içinde/onlar aracılığıyla bilinmesi, anlamlandırılması ve iletilmesi sürecidir. Böylece, gerçeklik toplumsal bir nitelik kazanacak ve bir anlamda yeniden yapılandırılmış, oluşturulmuş yani kurulmuş, inşa edilmiş olacaktır. "Gerçekliğin toplumsal inşası neden önemlidir?" sorusu konu bağlamında haklı bir sorudur ve "toplumsal olarak inşa edilmemiş, yani bilgisine toplumsal olarak sahip olmadığımız gerçeklik, toplumsal gelişme açısından genelde anlamlı bir gerçeklik değildir" biçiminde yanıtlanabilir. Dolayısıyla gerçekliğin toplumsal inşası yaşamsal öneme sahip bir gerekliliktir. McCarthy (2002, ss. 41-42)'e göre, gerçeklik toplumsal olarak yapılandırılan bir şeydir ve örneğin, bir gerçeklik türü olarak toplumsal gerçeklik kendi başına varolan bir görüngü değil, üretilen ve iletilen bir görüngüdür. Bir başka deyişle, "içinde yaşadığımız ve kendimizi yönlendirdiğimiz gerçeklikler, gelişimin her evresinde, toplumsallaştırılmış bir bilinç içeren toplumsal ve üretken bir sürecin parçasıdır (McCarthy, 2002, s. 46). Yine, Kongar (2002, s.

\footnotetext{
Bilgi kavramının çeşitli bağlamlarda değerlendirilmesi için bkz. Uçak, 1997; Önal, 1992; Akın, 2007; Anameriç,2007; Geyik ve Barca, 2007; Işık, 2007; Odabaş, 2007; Yılmaz, 2007; Yenişehirlioğlu, 1982; Hartmann, 1998
} 
35)'ın "çevremizdeki gerçek, toplumun gerçeğidir" belirlemesi gerçekliğin toplumsal niteliğini vurgular. Genel olarak, "gerçekliğin toplumsal inşası" konusunda bir anlamda kuramsal altyapıyı kurmaya başlayan bazı temel çalışmalar da bulunmaktadır. Berger ve Luckmann (2002) ile Gergen (2001)'in çalışmaları bunlar arasında öne çıkanlardır.

Toplumsal mekanizmalar kullanılarak bilinmeyen, anlamlandırılmayan ve iletilmeyen gerçeklik "ham gerçeklik" olarak nitelendirilebilir. Bu gerçekliğin toplumsal inşası ancak bilme, anlamlandırıma ve iletilme sürecinin gerçekleşmesi ile olanaklı olacaktır. Toplum yaşamına sokulmamış gerçeklik toplumsal olarak oluşturulmamış, inşa edilmemiş gerçekliktir. Bir örnekle açıklayacak olursak; Atlas Okyanusu'nda olan bir deprem bir gerçekliktir. O, olmuştur, vardır. Biz onu toplumsal yapının bir mekanizması olan jeolojik izleme araçları ile öğrendiğimiz, bildiğimiz anda gerçekliğin toplumsal inşa süreci başlar. O ham gerçek olmaktan toplumun bildiği bir gerçeklik durumuna gelir, yani gerçeklik toplumsal bir nitelik kazanır. O deprem gerçeğinin toplumsal inşası öncelikle toplum tarafından bilinmesi anlamına gelir. Gerçekliğin toplum tarafından bilinmesi inşanın toplumsal niteliğini yansıtan tek görüngü değildir. Sözü edilen toplumsal niteliği gerçekliğin inşa sürecine katan bir diğer nokta, bilme olayının toplumsal mekanizmalar sayesinde oluşudur. Bir başka deyişle, gerçekliği toplumsal yapının araçları ile bilebildiğimiz için gerçekliğin toplumsal inşasından söz ediyoruz.

Ancak, bilmek inşa süreci için ilk aşamadır. Sonraki aşama bu bilgiyi anlamlandırma sürecini içermektedir. Anlamlandırma, kısaca, nesnel olanın yani kendi başına bağımsız olarak var olanın iyi, kötü, güzel, çirkin, yararlı, doğru, yanlış, büyük, küçük, yavaş, hızlı, tehlikeli, zararlı vb. kavramlarla nitelenmesidir. Bir başka deyişle, anlamlandırma, kendi başına bu niteliklere sahip olmayan bir nesne, durum ya da olgunun insan yani toplum tarafından belirli nitelemelerle kodlanmasıdır. Bildiğimiz gerçekliğe bir nitelik, bir değer yüklemedir anlamlandırma. Aynı örnek üzerinden düşünecek olursak; "deprem tehlikelidir" önermesi bir anlamlandırmadır. Birey ya da toplum artık deprem denilen gerçekliğe bir anlam yüklemiş ve öyle algılamaya ve ona göre davranmaya başlamıştır. Toplum denilen yapı kültür adı altında bu türden anlamlandırmalarla varlığını sürdüren bir mekanizmadır. Bu nedenle anlamlandırma toplumsal yaşam için son derece önemlidir. Bir gerçeklik türü olarak "toplumsal gerçeklik, toplumsal oyuncular tarafından temsil edilmesini ve iletilmesini olanaklı kılan semboller ve anlamlardan oluşmaktadır... İnsanoğlu açısından varlığı, onu bize temsil eden araçlara dayanmaktadır" (McCarthy, 2002, s. 42).

Kuşkusuz, bilmenin/bilginin anlamlandırılması salt ona bazı nitelik yüklemelerle sınırlı tutulabilecek bir etkinlik değildir. Bir gerçekliğe ilişkin "veri"den (data), yani işlenmemiş bilgiden, işlenmiş bilgiye, yani enformasyona (information) geçiş, bir başka deyişle, veriyi enformasyona dönüştürme de bir anlamlandırma süreci olarak değerlendirilebilir. "Dışsal anlamlandırma" diyebileceğimiz "veriyi enformasyona dönüştürme" yukarıda sayılan toplumsal araçlar ile yapılmakta, bu nedenle gerçekliğin inşasına toplumsal nitelik kazandırılmaktadır. Ayrıca, bu dışsal anlamlandırmanın, yani enformasyonun, "içsel anlamlandırma"ya yani "knowledge olarak bilgiye dönüşmesi", 
bir başka deyişle, birey/toplum tarafından içselleştirilmesi de gerçekliğin toplumsal inşası anlamına gelmektedir. Headrick (2002, s. 13), bu "ham gerçekliği" ya da bu gerçekliğe ilişkin "veri”yi "örüntü" olarak adlandırmakta ve örüntüden enformasyona geçişten söz etmektedir. Ayrıca $o$, örüntünün insan enformasyonuna dönüşmesi için bunun insan tarafından kavranması gerektiğini belirtmektedir. Kısaca, veri ham gerçeklik, enformasyon anlamlandırılmış gerçeklik ve knowledge olarak bilgi de "iletilmiş / alımlanmış / algılanmış gerçeklik" olarak adlandırılabilir.

Gerçekliğin toplumsal inşası için son aşama, bilinen ve anlamlandırılmış olan gerçekliğin topluma iletilmesi ve bilme-anlamlandırma-iletme döngüsünün onlar için de başlatılmış olmasını gerektirir. Gerçekliğin, yine, toplumsal mekanizmalar aracılığıyla topluma iletilmemesi, toplumsal inşasının tamamlanmamış olması, yarıda kalması anlamına gelir. Yani, "tehlikeli bir jeolojik olay olan depremin nerede, ne zaman, hangi şiddette, ne kadar süreyle olduğu" bilgisinin topluma televizyon, gazete, kitap, internet vb. araçlarıyla sunulması anlamlandırılmış bilginin "iletilmesi” ve böylece gerçekliğin toplumsal inşa sürecinin tamamlanması demektir. İletme aşaması, hem bilginin hem de o bilgiye yüklenen anlamın iletilmesini içermektedir. İnşa sürecini oluşturan iletme, bir boyutuyla da anlamlandırmanın toplumsal üretimi ve toplumsallaştırımasıdır. Özellikle, kitle iletişim araçları olarak adlandırılan ve bilgiyi çok büyük insan topluluklarına iletme kapasite ve hızına sahip araçlarla anlam üretme, bunu yaygınlaştırma büyüklük anlamında nitelik değiştirmiştir. Ayrıca, kendisine toplumsal araçlar aracılığıyla iletilen gerçekliği, birey başkalarıyla paylaşarak da bu üretimi gerçekleştirmektedir.

Gerçekliğin toplumsal inşa sürecini bir soygun olayı örneği üzerinden de düşünebiliriz. New York'da bir bankanın soyulması olmuş olan, var olan bir gerçekliktir. Bilinmediği sürece ham bir gerçekliktir. Bu "bilinme" günümüz için alarm sistemi, telefon, telsiz, televizyon, gazete, internet, uydu, dergi haberi, kitap metninde geçen bir örnek vb. gibi toplumsal yaşamın yarattığı araçlar aracılığıyla gerçekleşmektedir. Sözü edilen gerçeklik sıralanan araçlardan oluşan toplumsal mekanizma sayesinde bilindiği anda gerçekliğin toplumsal inşa süreci başlamış olmaktadır. Aslında, gerçekliğin toplumsal mekanizmalar aracılığıyla bilinmesi dahi, başı başına, gerçekliğin inşasındaki toplumsal niteliği oluşturan bir etkinliktir. İlgili olaya ilişkin "bilme"den sonra yazılacak, söylenecek, gösterilecek "soygun yanlıştır" yargısı bir anlamlandırma, yani soygun gerçekliğine ilişkin toplumsal inşanın ikinci aşamasıdır. Toplum için soygun gerçeği "anlamlandırılmış bilmeye" konu olmuş olacak, yani gerçeklik toplumsallaştırılmış, toplumsal olarak inşa edilmiş olacaktır. Ancak bu inşa sürecinin tamamlanması için anlamlandırılmış bilginin yine topluma iletilmesi gerekmektedir. Böylece, toplum için bu gerçekliğe ilişkin bilme, anlamlandırma ve iletme süreci de başlatılmış olacaktır.

Görüldüğü gibi, gerçekliğin toplumsal inşa sürecinde yer alan bilme-anlamlandırmailetme aşamalarının her birisi toplumsal yapının/mekanizmanın araçları sayesinde gerçekleşmektedir. Sözü edilen inşa sürecine toplumsal niteliğini kazandıran da zaten sürecin bu mekanizmalar, yani toplumsal kurumlar ve toplumsal ilişkiler içinde gerçekleşmiş olmasıdır. 


\section{Gerçekliğin Toplumsal İnşasında Bilgi ve Bilgi Merkezi}

Kuramsal çerçevesini kısaca çizmeye çalıştığımız "Gerçekliğin Toplumsal İnşası" konusunu bilgi ve bilgi merkezi bağlamında irdelemek için üç noktayı ele almak gerekmektedir. Bunlardan ilki; "gerçekliğin toplumsal inşası"nın, yani gerçekliğin bilinmesi, anlamlandırılması ve iletilmesinin neden önemli olduğudur. İkincisi; gerçekliğin toplumsal inşasında bilginin işlevi ve yerinin ne olduğudur. Üçüncü olarak sözü edilen konuda bilgi merkezinin işlevi ve rolünü değerlendirmek gerekmektedir.

Gerçekliği bilmek neden önemlidir?

1. Her şeyden önce "bilmek" kendi başına önemlidir.

2. Gerçeklik (gerçek), bir anlamda, bilinirse vardır ya da bilindiği kadar vardır.

3. İnsan yaşamının değiştirilmesi ve geliştirilmesi, yani uygarlık gerçekliğin bilinmesine bağlıdır.

4. İnsan yaşamını geliştiren, uygarlığı yaratan en önemli etkinlik alanları olan bilim ve Felsefe "gerçekliği bilme" üzerine temellenmiştir. Bir başka alan olan sanat da gerçeklikten yola çıkar ve onu yeniden yaratmayı hedefler.

"Bilme"nin önemli olduğu önermesi sıradan bir belirleme olarak düşünülmemelidir. Bilimlerin anası sayılan, daha sonraki süreçte yolları bilimlerle ayrılan ama hala günümüzün en önemli insan etkinliklerinden birisi olan felsefe "bilgi" üzerine, "nasıl bilebiliriz" sorusu üzerine temellenen bir alandır. Bir başka önem ölçütü, bütün bilimlerin gerçekliği bilme amacı taşıması, bu işleve sahip olmasıdır. Bilmek, bilmeye çalışmak, bilmeye yardımcı olmak bütün bilimlerin özüdür. Bir başka deyişle, başlıca uygarlık çabası olan bilimsel uğraş en sağlam bilgi ve bilme peşindedir. Bilim olmadan, yani en sağlam bilme çabası olmadan insanlığın bugünkü gelişme noktasına ulaşması büyük olasılıkla olanaklı olamazdı. Dolayısıyla, biraz abartılı bir önerme gibi görünse de, insanın varlığı ve bu varlığını geliştirmesinin bilme etkinliğine bağlı olduğu söylenebilir.

En önemli noktalardan birisi, "dünya bize gösterildiği ölçüde vardır" (McCarthy, 2002, s. 15) önermesidir. Bir başka deyişle, gerçeklik, onun hakkında bilgimiz varsa bizim için vardır. Bilgisine sahip olmadığımız gerçeklik bizim için bir anlamda yoktur; nesnel olarak varsa da toplumsal gelişme açısından işlevsizdir. Dolayısıyla, bilmek, aslında "var kılmak", nesne, olay ve olgulara bir boyutuyla "varlık kazandırmak" anlamına gelir. Bu nokta uygarlık süreci açısından son derece önemlidir. Montaigne'nin Denemeler'de "bu dağlarla sınırlanan ve onların öte taraflarındaki dünyada olan gerçeklik" ya da Pascal'ın Düşünceler'inde "gerçek Pireneler'in bu yanında hatta öbür yanında” deyişi (Burke, 2004) gerçekliğin bilgimizle sınırlı olduğu, gerçekliği yok yapan dağların bilgisizlik, bilmemek, onun bilgisine sahip olmamak anlamına geldiği söylenebilir. Yani, dağların ya da Pireneler'in öteki tarafı bilmediklerimizdir ve bunlar bizim için aslında yoktur. Bilgimizle, bilerek varlaştıramadığımız, var kılamadığımız gerçekliği anlamlandırmak ve değiştirmek olanaklı değildir. McCarthy (2002, s.15), bunu 
"Gerçeklik insanların onun hakkındaki bilgileri kadar değişkendir. Söz konusu gerçeklik hakkında bize açıklama getirecek bilgimiz yoksa gerçeklik de yoktur" belirlemesi ile zenginleştirmektedir. Kuşkusuz, burada idealist bir felsefi yaklaşımla "gerçekliği bilginin yarattığını" söylemiyoruz. Tam tersine "gerçeklik bilgiyi yaratmaktadır". Ancak, bilinmeyen gerçekliğin öznel anlamda var olmadığını, ona bu anlamda varlık kazandıran unsurun onun hakkındaki bilgimiz olduğunu öne sürüyoruz.

Gerçeklik-bilgi ilişkisinde bilginin niteliğine de bakmak gerekmektedir. Cornforth (1997, s.176)'un dediği gibi, bilgi özünde, toplumsal bir üründür. İnsanların toplumsal faaliyetinin bir ürünü biçiminde, toplumsal olarak inşa edilir. O, toplum içinde kazanılır ve inşa edilir. Yani, gerçekliğe bir anlamda varlık kazandıran bilgi toplum dediğimiz yapı içinde üretilir ve bu nedenle de toplumsal niteliğe sahiptir. Hekman (1999, s. 70)'ın "düşüncenin toplumsal belirlenimi" vurgusu, bir anlamda bilginin toplumsal niteliğini dile getirir.

Bilgiye, yani onun üretimine toplumsal nitelik kazandıran toplum içinde, toplum dediğimiz mekanizma içinde bunu sağlayan kurumlardan birisi de bilgi merkezi (arşiv, kütüphane) dir. Bilgi merkezi, bilginin üretilmesi için bilgiyi bulan, kayıt altına alan, düzenleyen ve bilgi üretecek olana sunan toplumsal bir kurumdur. Dolayısıyla, bilgi merkezi bilgiye toplumsal nitelik kazandıran, gerçekliğin toplumsal inşasında rol alan bir kurumdur. Bilgi merkezi gerçekliğe ilişkin açıklamalar olan bilgiyi ileten, ona aracılık eden toplumun yarattığı bir kurum, toplumsal bir kurum olduğu için gerçekliğin toplumsal inşasında işlev yüklenmektedir. Kısaca;

1. Gerçekliğin insan/toplum için varlık kazanmasında bilgi zorunludur. Yani, gerçeklik bizim için onun hakkında bize ulaştırılan bilgi ile varlık kazanır. Gerçekliği bilgi ile yeniden ve toplumsal olarak inşa ederiz.

2. Bilgi, toplumsal yapı içinde üretilen ve yeniden üretilmesi için iletilen bir nesnedir. Gerçekliği yeniden inşada kullandığımız bilgi toplumsal niteliğe sahip olduğu, yani toplum mekanizması içinde üretildiği için gerçekliğin toplumsal inşası söz konusu olmaktadır.

3. Bilgiye toplumsal niteliğini kazandıran kurumlardan birisi de bilgi merkezidir. Çünkü bilginin üretiminde, o, zorunlu bir toplumsal kurumdur.

O halde, bilgi merkezi;

Gerçekliğin toplumsal inşası sürecinde bilginin üretim ve iletimine katkı sağlayan toplumsal mekanizmanın parçası olduğu için rol alır. Gerçekliğin toplumsal inşasındaki önemini ortaya koyan nokta bilgi merkezi kurumunun bu süreçteki işlevidir.

Toplumsal olarak inşa edilmemiş, yani bilgisi oluşturulmamış gerçekliğin uygarlık açısından geneldeki işlevsizliği bağlamında düşünüldüğünde bilgi merkezinin önemi daha anlaşılır olmaktadır.

Cornforth (1997, s.44), "dünya hakkında düşünebilmemiz için, önce dünyayı algılamamız gerekir” belirlemesi, insana temel niteliğini veren düşünme sürecinde gerçekliği bilmemizin dolayısıyla bilginin önemine işaret eder. "Gerçeklik, bilgi 
süreçlerinin başarısıdır" (McCarthy, 2002, s. 42) vurgusu gerçekliğin toplumsal inşasında bilginin işlevine işaret eder. Düşünmenin nesnesi gerçekliktir; onu algılamadan, yani bilmeden düşünemeyiz. Bilgi, algılamadır ve toplumsal olarak üretilir. Bilgi merkezi, gerçekliğin bilgi aracılığıyla algılanmasında işlev üstlenmektedir. Dolayısıyla, bilgi merkezi, gerçekliğin algılanmasında yani bilinmesinde rol alır ve bu rol alış gerçekliğin inşasına toplumsal nitelik kazandıran bir süreç anlamına gelir. Nitekim Burke (2004), eserinde bilginin toplumsal gerçeği bilmek için bir toplumsal nesne olarak serüvenini anlatır. Kuhn'a göre de, "gerçekler ortaya çıkar ve algılanabildiği ve kabul edilebildiği bir tür düşünme biçimiyle bilinir" (McCarthy, 2002, s. 42).

Gerçekliğin toplumsal inşa sürecindeki ilk aşama "bilme" kadar ikinci aşama olan onu "anlamlandırmada" da bilgi ve bilgi merkezinin işlevi görülebilir. Açıklandığı üzere, gerçekliğin anlamlandırılması onun "ham" durumundan "pişmiş" duruma getirilmesidir. Gerçekliğe bir nitelik yükleme, "veri"den "information"a geçişi sağlama ya da "dışsal gerçeklikten içsel gerçekliğe dönüştürme" olarak içeriklendirdiğimiz anlamlandırma aşaması gerçekliğin algılanabilmesinde son derece önemlidir. Anlamlandırma gerçekliğin algılanmasını kolaylaştıran ve belki de sağlayan bir süreçtir. Bilgi süreci ham bilginin (verinin) işlenme ve iletilme aşamalarını içerir. Gerçeklik bilgi ile anlamlandıııır ve bu anlamlandırılmış bilgi ya da gerçeklik bilgi merkezi aracılığıyla iletilir. Bilgi merkezinin gerçekliğin toplumsal inşasındaki diğer bir işlevi bu noktada ortaya çıkmaktadır. "Bilgilerin toplumsal olarak üretilmesi ve dağıtılması" (McCarthy, 2002, s. 39) olgusu bilgi merkezini gerçekliğin toplumsal inşa sürecine katan bir boyuttur. Çünkü bilgi merkezi gerçeklikle toplum arasında köprü olan toplumsal bir kurumdur. Bir başka deyişle, bilgi merkezi, bilinenle bileni buluşturan bir toplumsal kurumdur. Nitekim Burke (2004, s.27), daha 15-18. yüzyıllarda, kütüphanecilere gerçekliğin bilgisini aktaran "aracılar" denildiğinden söz eder. Jowett'nin "bildiğimden ötede bilgi yoktur... Benim bilmediğim bilgi değildir" (Cornforth, 1997, s. 186) yaklaşımı bilgi merkezinin bilme eylemindeki işlevini bir başka biçimde ortaya koyan bir belirlemedir. Çünkü bilme için gerçekliğin bilgisinin isteyene aktarılması zorunludur. Bilgi merkezi bilgiyi aktaran toplumsal bir kurumdur. 16. yüzyılda "bilgi intilali" deyimiyle, bilginin o dönemdeki yayılma sürecine gönderme yapılır. Liman kentlerinde yaşayan halk, her zaman, yeni gelen gemilerin denizcileriyle konuşmak için kıyıya giderdi. Buraları farklı türden insanlar kadar farklı bilgi türlerinin de başlıca karşılaşma yerleriydi (Burke, 2004, s. 61). Sözü edilen dönemler de dahil bilgi merkezleri çağlar boyunca insanların bu şans eseri ya da rastlantısal bilgi edinme sürecini disipline eden, toplumsallaştıran bir mekanizmanın parçası olmuşlardır. Dolayısıyla, bilgi merkezi, bilginin anlamlandıııması ve anlamlandırılmış bilginin iletilmesinde işlev yüklenerek gerçekliğin toplumsal inşasında rol almaktadır. Çünkü "bilgiler, tarihsel açıdan farklılık gösteren toplumsal etkileşim, iletişim ve örgütlenme biçimlerinden ayrı tutulamaz" (McCarthy, 2002, s. 51). Bilgi merkezi, gerçekliğin anlamlandırımasını toplumsallaştıran bir aracı kurumdur. Gerçekliğe ilişkin anlamın toplumsal üretimi, yani toplumsal düzeyde oluşturulması ve dağıtımı gerçekliğin toplumsal inşasında temel konudur ve bilgi merkezi bu konuda ciddi işlevler yüklenir. "Toplumsal gerçekliğin kendi başına toplumsal bir olay olmayışı, üretilen ve iletilen, anlamı bu iletişim sistemleri içinde ve aracılığıyla oluşturulan bir şey olması" (McCarthy, 2002, s. 45) bilgi merkezinin sözü edilen işlevinin temel kaynağına işaret etmektedir. 
Gerçekliğin toplumsal inşasında gerek bilme/algılama gerekse anlamlandırma aşamaları gerçekliğe ilişkin bilginin iletilmesi zorunluluğunu içermektedir. Gerçekliğin varlık kazanması onun hakkındaki anlamlandırılmış bilginin toplum tarafından elde edilmiş olmasını gerektirmektedir. Bilginin iletimi, yani gerçekliğin toplumsal inşasındaki son aşamanın yerine getirilmesinde bilgi merkezi doğrudan işlev yüklenmektedir. Gerçekliğe ilişkin bilgi toplumsal mekanizmalar aracılığıyla iletilir. Yukarıda açıklandığı üzere, bilgi merkezi, bilgiyi ileten toplumsal bir kurumdur. Bilginin toplumsal iletiminde en önemli rolü üstlenen kurumlardan bilgi merkezi böylece gerçekliğin inşasına toplumsal nitelik katar. Gerçekliğe ilişkin bilgi iletilmediğinde gerçekliğin toplumsal inşa süreci tamamlanmamış olur. İşte, sürecin tamamlanmasında bilgi merkezi iletme görevine sahiptir. Bir başka deyişle, bilgi merkezi, gerçekliğin toplumsal inşa sürecine bilgiyi ileten toplumsal mekanizmanın parçası olma işlevi ile katkıda bulunur. Bu katkıyı, bilgi merkezinin gerçekliğin toplumsal inşasındaki en önemli işlevi saymak yanlış olmayacaktır.

Gerçekliğe ilişkin bilginin iletiminde doğruluk-yanlışlık ya da öznellik-nesnellik sorunu bilgi merkezinin sözü edilen inşa sürecine katkısını anlamlı duruma getiren bir başka olgudur. Gerçekliğe ilişkin birçok bilgi üretilmekte ve bu bilgilerin bir bölümü yanlış ya da güvenilmez olabilmektedir. Gerçekliğin "doğru” toplumsal inşasında gerçekliğe ilişkin "doğru" bilginin iletilmesi son derece önemli bir konudur. Yanlış bilgi gerçekliğin yanlış inşasına neden olabilecektir. Örneğin, "yıldırım düşmesi” gerçeğine ilişkin bilgiyi "Tanrı'nın bir uyarısı ya da cezası" olarak üretilir ve toplumsallaştırııır, yani topluma iletilirse, bu fiziksel olaya ilişkin paratoner geliştirme yerine ahlaksal önlemlere başvurulmasına ve bir anlamda sorunun çözümlenmemesine yol açılabilir. Böylece, gerçeklik toplumsal olarak yanlış inşa edilmiş olur. Ya da "Dünya düzdür!" bilgisini kişisel web sayfasına koyduğumuzda, bu, gerçekliğin toplumsallaştırımış yanlış bilgisi olacaktır. Aynı gerçekliğe ilişkin farklı bilgi, farklı anlamlandırmalara, bu da farklı sonuç, etki, yansımalara ve iletime neden olabilecektir. Dezenformasyon da denilen bu durum gerçekliğin toplumsal inşasında ciddi bir soruna işaret etmektedir. Bilgi merkezi, gerçekliğe ilişkin bilgileri bazı güvenilirlik ölçütlerine göre seçerek, belirli ölçüde denetleyerek toplumsallaştıran bir kurum olma niteliği ile de gerçekliğin "doğru" inşasına katkıda bulunur.

Bilgi merkezi-gerçekliğin toplumsal inşası ilişkisi üzerine düşünülmesi gereken bir başka nokta, yaşadığımız çağda bilgi teknolojileri alanındaki gelişmelerin boyutu ve hızıdır. Bilgi teknolojileri, McCarthy (2002, s. 44)'nin de dediği üzere, "gerçekliği daha hızlı ve kesin biçimde aktarmaya odaklanmıştır". Dolayısıyla, gerçekliğin toplumsal inşa süreci hızlanmış, inşa sürecindeki iletimin boyutu önemli toplumsal eşitsizlikleri de içeren biçimde genişlemiş ve yanlış bilgi iletimi, yani dezenformasyon riski artmıştır. Bilgi merkezi, gerçekliğin toplumsal inşasında bilginin iletimi koşulunu belirli ölçüde de olsa nesnel, disiplinli ve denetimli biçimde yaparak işlev yüklenir. Bilgi merkezinin, işlevini denetimli yapması dezenformasyonu azaltmaya ciddi katkılar sağlamaktadır. Ancak, bunun da ötesinde, gerçekliğin toplumsal inşa süreci çağdaş bilgi teknolojileri ile büyük bir hız kazanmıştır. Bu hız olanağını sağlayan kurumlardan birisi de bilgi merkezidir. Bir başka deyişle, bilgi merkezi, kullandığı ve kullandırdığı 


\section{bilgi teknolojileri ile gerçekliğin toplumsal inşa sürecini hızlandırmış ve yaygınlaştırmıştır.}

\section{Sonuç}

İnsan, sınırlı içgüdüsel yetenekleri dışında toplumsal olarak bilebilir. Bilmek, toplumsal nitelikli bir eylemdir; toplum olmazsa insan bilemez. Toplumsal olarak bilmemizi sağlayan kurumlarda birisi bilgi merkezidir. Bir başka deyişle, bilgi merkezi, gerçekliği, yani dünyayı bilmemizi sağlayan bir toplumsal kurumdur. Bilgi merkezi, bilmemizi sağlar; yani o, dünyayı bilinebilir kılar. Bilmek varlığın ve bu varlığımızı geliştirmenin temel koşuludur. Bilgi merkezi bilmemizi sağlayarak insana varlık kazandıran ve bu varlığını geliştiren bir kurumdur. Bilgi bir güçtür; bilginin bu güce sahip olmasının kaynaklarından birisi de bilgi merkezidir. Diğer bir deyişle, bilgi merkezi, bilgiye güç kazandıran toplumsal bir kurumdur.

"Gerçekliğin toplumsal yapı ve mekanizmalar içinde, onlar aracılığıyla yapılandırılması, kurulması, oluşturulması, bilinebilir, algılanabilir duruma getirilmesi, anlamlandırılması ve iletilmesi süreci” olarak ele aldığımı gerçekliğin toplumsal inşası olgusunu bilgi kavramı ve bilgi merkezi bağlamında değerlendirmek Bilgi Yönetimi alanına kuramsal açılımlar sağlamaktadır. Bu açılımlar ise alanın uygarlık ve yaşam için önemini bilimsel düzeyde ortaya koymaktadır. Bu çalışmanın belki de en genel sonucu "Bilgi merkezi önemlidir!" önermesidir. Ancak, bu önermenin anlamlandırılarak algılanması ve iletilerek toplumsallaşması süreci, en azından Türkiye için hiç de kolay görünmemektedir. Bu konudaki kuramsal çabalar ile uygulama başarılarının sonucu belirleme olasılığı yüksektir. Bu çerçevede, Bilgi ve Belge Yönetimi ile diğer alanlar/ disiplinler arasında kuramsal düzeyde daha sıkı ve anlamlı ilişkiler kurulmaya çalışılmalı ve bu ilişkilerden hareketle uygulamaya dönük eylem önerileri geliştirilmelidir.

\section{Kaynakça}

Akın, H. B. (2007). Dünü ve geleceğiyle bilgi toplumu. H. Odabaş ve H. Anameriç (Yay. Haz). Bilgi içinde (ss. 1-22). Ankara: Referans Yayıncılık.

Anameriç, H. (2007). Bilgi sistemleri. H. Odabaş ve H. Anameriç (Yay. Haz). Bilgi içinde (ss. 2344). Ankara: Referans Yayıncılık.

Berger, P. L. ve Luckmann, T. (2002). The social construction of reality. C. Calhoun ve diğerleri (Yay. Haz.). Contemporary Sociological Theory içinde (ss. 42-50). London: Blackwell Publishing.

Burke, P. (2004). Gutenberg'den Diderot'ya bilginin toplumsal tarihi (M.Tuncay, Çev.). İstanbul: Tarih Vakfı Yurt Yayınları.

Cornforth, M. (1997). Bilgi teorisi (H. Selman, Çev.). İstanbul: Yorum.

Denkel, A. (1998). Bilginin temelleri. İstanbul: Metis.

Gergen, K. J. (2001). Social construction in context. London: Sage Publication. 
Geyik, M. ve Barca, M. (2007). Bilgi üretimi ve etkin bilgi üretimi sağlayacak örgütsel tasarımların ipuçları. H. Odabaş ve H. Anameriç (Yay. Haz). Bilgi içinde (ss. 55-80). Ankara: Referans Yayıncılık.

Hartmann, N. (1998). Ontolojinin ışığında bilgi (H.Tepe, Çev.). Ankara: Türkiye Felsefe Kurumu.

Headrick, D. R. (2002). Enformasyon çağı: Akıl ve devrim çağında bilgi teknolojileri 1700-1850 (Z.Kılıç, Çev.). İstanbul: Kitap Yayınevi.

Hekman, S. (1999). Bilgi sosyolojisi ve Hermeneutik (B. Balkız ve H.Arslan, Çev.). İstanbul: Paradigma.

Işık, Y. (2007). Bilgi ekonomisi ve Türkiye ekonomisinin gelişme perspektifi. H. Odabaş ve H. Anameriç (Yay. Haz). Bilgi içinde (ss. 81-98). Ankara: Referans Yayıncılık.

Kongar, E. (2002). Toplumsal değişme kuramları ve Türkiye gerçeği (9.bs.). İstanbul: Remzi.

McCarthy, E. D. (2002). Bilgi kültürü: Yeni bilgi sosyolojisi (A. F.Yılmaz, Çev.). İstanbul: Çivi Yazıları.

Odabaş, H. (2007). Bilgi yönetimi. H. Odabaş ve H. Anameriç (Yay. Haz). Bilgi içinde (ss.99-108). Ankara: Referans Yayınclık.

Önal, İ. (1992). Bilgi gereksinimlerinin karşılanması ve okul kütüphaneleri. Yayımlanmamış doktora tezi, Hacettepe Üniversitesi, Ankara.

Uçak, N. Ö. (1997). Bilim adamlarının bilgi arama davranışları ve bunları etkileyen nedenler. Yayımlanmamış doktora tezi, Hacettepe Üniversitesi, Ankara.

TDK. (1983). Türkçe Sözlük (7.bs.). Ankara: TDK.

Yenişehirlioğlu, Ş. (1982). Felsefe diyalektik bilgi kuramı (Epistomoloji). Ankara: Ankara Üniversitesi.

Yılmaz, B. (2007). Bilgi sosyolojisi ve kütüphanecilik kuramı. H. Odabaş ve H. Anameriç (Yay. Haz). Bilgi içinde (ss. 167-188). Ankara: Referans Yayıncılık.

Yontar, A. (2004). Türkiye'de kütüphane ve enformasyon bilimi teorisi: Temel sorunlar. S. Arslantekin ve F.Özdemirci (Yay.Haz.). A.Ü. DTCF Bilgi ve Belge Yönetimi Bölümü Kütüphaneciliğin Destanı Uluslararası Sempozyumu 21-24 Ekim 2004, Ankara Bildiriler içinde (ss.14-30). Ankara: Ankara Üniversitesi. 